\section{Gift to University of Leeds}

Mr. Charles Brotfierton has just given the University of Leeds (1) $£ 1,000$ a year for seven years for the establishment of a Brotherton research fellowship in physical chemistry tenable in the Department of Colour Chemistry and Dyeing; (2) $£ 1,000$ a year for seven years for the establishment of a new lectureship in chemical engineering in the Department of Coal Gas and Fuel Industries; and (3) an additional sum of $£ 1,000$ to each of the two Departments for the purchase of equipment.

These are not the first gifts which have come to the University of Leeds from Mr. Brotherton. In September 1940 he provided a valuable addition to the resources of the Colour Chemistry and Dyeing Department by providing funds for the institution of two Charles Brotherton entrance scholarships tenable by students reading for the degree of B.Sc. with honours in colour chemistry, and two years later he increased the number of scholarships to three. Mr. Brotherton has expressed his gratification at the success of this scheme and has now extended his interest in the work of the Department by his further contributions. For some time past the investigation of problems of fibre technology, dyeing and some aspects of colour chemistry has necessitated the increasing application of methods of physical chemistry. The addition of a physical chemist to the staff of the Department has long been desirable; but the mere institution of such a post would have been ineffective in the absence of a suitably equipped laboratory. Mr. Brotherton's generous gift, which allows complete freedom in the expenditure of the funds as between the salary of the research fellow and the equipment of an appropriate laboratory, will make possible at an early date the realization of this most important development.

The Department of Coal Gas and Fuel Industries with Metallurgy, which also benefits by Mr. Brotherton's latest gift, co-operates with the Institution of Gas Engineers in research supported by the Institution and guided by a joint committee of the Institution and the University of Leeds. The Livesey professorship was endowed in 1908 from a fund raised by public subscription from the gas industry in memory of the late Sir George Livesey. The Department has for some thirty-seven years provided degree courses in fuel and metallurgy. The training in gas engineering has been based on chemistry and engineering, followed by instruction embracing chemical engineering and fuel technology, mainly to meet the needs of the gas industry. A separate curriculum was established in 1942 in chemical engineering and is intended to provide instruction particularly in plant design and in the so-called unit processes of the chemical industry. It meets the special need of those passing either into the contracting side of the gas industry or into the chemical industry generally. The provision of up-todate equipment and staff in such technological departments is costly, and the University has largely to rely on the support of industry. Mr. Charles Brotherton's generous gift to provide for the special needs of chemical engineering is most opportune and should materially help to establish one of the best training grounds in the country. The need is vital, for British universities have been unable during the years between the two wars to make advances in this field comparable with those of the United States.

\section{An International Association of University Teachers}

THE sixth general meeting of the Association of Allied University Professors was held in London on September 25. The meeting was called specially to consider the statutes for a proposed International Association of University Professors and Lecturers. These were, after some amendment, adopted as provisional statutes, so that what has hitherto been a domestic association, bringing together those university professors and lecturers of the Allied countries who, in recent circumstances, have reached Great Britain, now takes on a wider international function under a new name. It is hoped that in each country where there is academic freedom a national group of members may come into existence. In order to establish contacts and bring into being such groups, a Provisional Central Council has been formed, mainly of university teachers of various nationalities who are domiciled in Great Britain, the duty of each member of which is to arouse interest in the Association in the universities of his own country. As soon as circumstances permit, representatives from these countries will replace the original provisional member and the Central Council will become a representative body, and will confirm or amend the statutes. The Provisional Central Council at present comprises members representing some twenty different countries, and it will be enlarged as further contacts are made. One result of the change in structure of the Association will be that in Great Britain, where membership has hitherto been restricted in order to preserve some balance between British members and those from other countries, membership will now be widely open in university circles. After the more formal business of the meeting was completed, Dr. Grayson N. Kefauver, of the American Educational Delegation, gave an address on "The Role of the University in Social Reconstruction".

\section{British Standards Institution}

THE annual general meeting of the British Standards Institution was held on October 17, when Lord Woolton was elected president, Sir Percy Ashley vicepresident, and Sir William Larke succeeded Sir Percy Ashley as chairman of the General Council. Dr. E. F. Armstrong, chairman of the Finance Committee, explained that the income and expenditure for the year had increased by 28 per cent and was now about $£ 69,000$. The sales of copies of British Standards had gone up 39 per cent. The Government grant-inaid was nearly double and was now $£ 12,900$. While there was an increase of some 15 per cent in the number of subscribing members he pointed out the need for greater support from local authorities and industry. Sir Percy Ashley concluded his term of office as chairman of the General Council with a brief review of the work done as a direct aid to the war effort by the British Standards Institution, and the progress made during the same period in the preparation of British standards for industrial and commercial materials end appliances. The war work covered the preparation of war emergency British standards for A.R.P. materials for the Ministry of Home Security, packaging schedules and code for the Ministry of Production, steel and non-ferrous metal standards as well as standards for many other materials, tools and appliances for the Ministry of Supply and for the Services generally, and schedules for clothing and hardware for the Board of Trade. Many of the war emergency standards were made 
compulsory by the issue of statutory rules and orders. The preparation of standards for building materials and appliances now being carried out in support of the programme of house-building of the Ministries of Works and Health has already reached substantial proportions. Sir Percy concluded by emphasizing the importance of industrial standards, which provide for accurate and precise trade descriptions, methods of sampling and testing, and standards of performance, and of an independent body, set up and maintained by the national industry as a whole, with Government support but not under Government control; for the preparation of such standards. Progress will be most widespread and continuous if the policy of 'standardization by consent' is consistently pursued.

\section{Harvesting Machinery}

THE inaugural meeting of the 1944-45 session of the Institution of British Agricultural Engineers was held on October 17 at the Institution of Electrical Engineers under the chairmanship of Mr. C. I. C. Bosanquet, and Mr. Cornelius Davies read a paper on harvesting machinery. Mr. Davies, who has for many years been closely associated with the South-Eastern Agricultural College at Wye, Kent, traced the developments in methods of harvesting from the earliest times to the present day. His paper dealt not only with the harvesting of corn and potatoes but also with machinery for handling sugar beet, grass, silage, hops, vegetables and fruit. On the combine harvester Mr. Davies reminded the audience that this machine cuts and threshes the grain in one operation, and there is no period in the stook when final ripening can take place. Adequate drying facilities are necessary, and serious attention to grain storage is required. Nearly all combine owners are faced with a straw problem. $\mathrm{He}$ considers that to burn straw is evidence of bad husbandry. On some farms pick-up balers are used, but the cost of these is nearly as high as that of a combine; further, the use to which the baled straw can be put must be considered.

On the question of potato harvesting Mr. Davies discussed the relative merits of the spinner and the elevator lifter, and stressed the need that still exists for a really satisfactory potato harvester. In conclusion, Mr. Davies stated that in addition to the provision of more and better harvesting machines, there must be more skill in handling and greater care in maintaining and managing agricultural machinery. In the discussion which ensued, community ownership of expensive machines, the employment of contractors, and the development of simple and relatively inexpensive machines within the scope of private ownership on small farms were discussed.

\section{Cultural Co-operation}

UNDER the title "The Cultural Co-operation Program 1938-1943" (Washington: Govt. Printing Office. 15 cents), the U.S. Department of State has issued a report by $H$. Hanson describing the development since its inception of this programme for fostering international relations on a basis of mutual understanding and appreciation. The programme is conceived by the General Advisory Committee of the Division of Cultural Relations as a long-term one of continuing activities which should be as broad as intellectual and cultural activities themselves. A statement of policy issued by the Department on March 31, 1944, on the participation of the United
States in educational and cultural reconstruction in Europe, indicated the Department's intention of co-operating in the formation of a United Nations organization for educational and cultural reconstruction. This emergency programme to meet this need may consist of assistance in restocking essential educational facilities, especially books and scientific and other teaching aids; in the provision of opportunities for training carefully selected foreign students in American educational institutions; in re-establishing essential library facilities; and in the recovery and restoration to their rightful owners of scientific, artistic and archival materials looted by the Axis countries. The report includes some notes on professional and scientific relations, and on the various activities under the programme: these include travel and study grants, including student exchange, and the provision of technical experts for China; cultural centres, such as libraries, including the reference library opened by the Office of War Information in London in December 1942, which seeks by a careful loan service to place each new American book in the hands of selected people in the British Isles; cultural materials, such as books for libraries in the Western hemisphere, book translations, microflims for China and the Near East, science news letters and motion pictures and radio activities.

\section{Pitfalls of Positivism}

IN a most timely article entitled "Positivism" (Mind, July 1944), Prof. W. T. Stace throws great light on the doctrinaire character of the so-called logical positivists. After making a useful distinction between the 'meaning' of a word and the 'significance' of a sentence, he states the positivist principle as follows: "what makes a sentence significant is that some actual or possible observation can be deduced from it in conjunction with certain other premises, without being deducible from those other premises alone". He then makes his main point, that underlying this principle is another one more fundamental, which he calls the "Principle of Observable Kinds", and states as follows, "a sentence, to be significant, must assert or deny facts of a kind such that it is logically possible directly to observe some facts which are instances of that kind".

Prof. Stace points out that this principle is different from the positivist principle in that it introduces the notion of direct verification, whereas the positivist principle makes use of that of indirect verification. Further, this latter principle neither follows from the positivist principle nor is it self-evident. Nor again does it follow from the empiricist principle which states that all our simple ideas come from impressions, because this provides no guide as to how the former are to be combined to make significant sentences. In fact, Prof. Stace holds that there is no reason to think the principle true. It would follow that we should discard it and with it the positivist principle, if in fact this latter is based on it. But the proof which Prof. Stace gives that the two are related in this way is weak. Nevertheless, all those inclined to flirt with modern forms of positivism should study the article.

\section{Physical Society's Exhibition of Scientific Instru- ments and Apparatus}

THE Physical Society's long and almost continuous series of annual exhibitions of scientific instruments and apparatus was, of necessity, suspended during the War. Its resumption has recently been considered by the Council of the Society and by the Exhibition 